IZA DP No. 6729

Delayed Entry into First Marriage: Further Evidence on the Becker-Landes-Michael Hypothesis

Evelyn L. Lehrer

Yu Chen

July 2012 


\title{
Delayed Entry into First Marriage: Further Evidence on the Becker-Landes-Michael Hypothesis
}

\author{
Evelyn L. Lehrer \\ University of Illinois at Chicago \\ and IZA \\ Yu Chen \\ University of Illinois at Chicago
}
Discussion Paper No. 6729
July 2012

IZA
P.O. Box 7240
53072 Bonn
Germany
Phone: +49-228-3894-0
Fax: +49-228-3894-180
E-mail: iza@iza.org

\begin{abstract}
Any opinions expressed here are those of the author(s) and not those of IZA. Research published in this series may include views on policy, but the institute itself takes no institutional policy positions.

The Institute for the Study of Labor (IZA) in Bonn is a local and virtual international research center and a place of communication between science, politics and business. IZA is an independent nonprofit organization supported by Deutsche Post Foundation. The center is associated with the University of Bonn and offers a stimulating research environment through its international network, workshops and conferences, data service, project support, research visits and doctoral program. IZA engages in (i) original and internationally competitive research in all fields of labor economics, (ii) development of policy concepts, and (iii) dissemination of research results and concepts to the interested public.
\end{abstract}

IZA Discussion Papers often represent preliminary work and are circulated to encourage discussion. Citation of such a paper should account for its provisional character. A revised version may be available directly from the author. 


\section{ABSTRACT}

\section{Delayed Entry into First Marriage: Further Evidence on the Becker-Landes-Michael Hypothesis"}

In their pioneering research, Becker, Landes and Michael (1977) found that beyond age 30 there is a positive relationship between women's age at first marriage and marital instability. They interpreted this finding as a "poor-match" effect emerging as the biological clock begins to tick. In analyses of the 2006-2010 National Surveys of Family Growth (NSFG), we find evidence of the existence of this effect: women who delay marriage disproportionately make unconventional matches, which are generally associated with high marital instability $(\mathrm{N}=$ $3,184)$. We also find, however, that their unions are very solid. We develop and test competing hypotheses that can account for these patterns. In addition, noting that women's delayed transition to first marriage has been accompanied by higher proportions of women entering marriage with 16 years of schooling or more, we examine changes across the last three NSFG cycles in the education - marital instability association.

JEL Classification: J12

Keywords: divorce, marital stability, marital instability, marriage, marriage dissolution

Corresponding author:

Evelyn L. Lehrer

University of Illinois at Chicago

Department of Economics (m/c 144)

601 South Morgan Street

Chicago, Illinois 60607-7121

USA

E-mail: elehrer@uic.edu

\footnotetext{
* We gratefully acknowledge valuable comments on earlier drafts of this paper from Shoshana Grossbard, Sonia Oreffice, Christine Schwartz, Kristina Terkun, Bradford Wilcox, and participants at the annual meetings of the Illinois Economic Association (Chicago, October 28-29, 2011) and the Population Association of America (San Francisco, May 3-5, 2012).
} 
The steady increase in age at first marriage has been one of the most salient demographic trends in the U.S. landscape in recent decades. The median age rose from 20 and 23 for women and men, respectively, in 1950-1960, to 26 and 28 in 2010 (U.S. Census Bureau, 2010). Several factors contributed to this trend, including the development of oral contraception and the legalization of abortion, the growth in cohabitation, changes in household technology, and the decline in the male-female wage gap (Cherlin, 2004; Goldin \& Katz, 2002; Greenwood \& Guner, 2008; Isen \& Stevenson, 2012). The focus of this paper is on the growing number of women in the U.S. who are entering marriage in the late twenties or thereafter: What are the characteristics of the unions that they form? Are such unions stable?

Two main theoretical concepts are relevant to these questions. First, Becker (1973) developed the idea that in the optimal sorting there is positive assortative mating for traits that are complementary within the context of marriage (e.g., education, religion, ethnicity) and negative assortative mating for those that are substitutes (e.g., productivity characteristics). When such sorting does not occur along important dimensions, so that there is a mismatch and the resulting gains from marriage are low, the outcome is a high probability of divorce (Becker, Landes, \& Michael, 1977; Becker, 1990). Expanding on these insights, Oppenheimer (1988) advanced the notion of a "maturity effect:” marriages contracted at an early age are at a higher risk of disruption because they are more likely to be based on mistaken expectations. At young ages individuals have inadequate self knowledge and are uncertain about their own and their partners' potential trajectories. Moreover, some of their adult attributes have not yet emerged, making assortative mating by such traits impossible. Thus the maturity effect- encompassing a range of factors far broader than purely emotional maturity- postulates that postponement of entry to first marriage has a stabilizing influence. The maturity effect may be reinforced by the 
positive association between age at first marriage and length of marital search, at the extensive margin (additional information about various potential partners) and at the intensive margin (further information about serious prospects) (Becker, 1990; Weiss \& Willis, 1997). Longer search at both margins facilitates a good match, although diminishing returns to search likely set in at some point.

Second, Becker et al. (1977) suggested the possibility of non-linearities, with a "poor match” effect emerging at older ages. The authors hypothesized that the ticking of the biological clock would likely lead women who reach their late twenties/thirties in the single state to revise their expectations downward and settle for a partner who is far from the optimal match, with adverse consequences for marital stability. Postponing entry to first marriage this much could thus have a destabilizing influence, reinforced by the thinning over time of the potential partner pool. If this effect is strong enough, the relationship between age at first marriage and marital instability (without controlling for the spouses' characteristics at the time of marriage) would be U-shaped: after a certain point, age at marriage and the probability of dissolution would be positively related.

The concepts discussed above suggest direct, causal effects of opposing directions of an older age at first marriage on marital instability. Postponement of entry to marriage may also influence marital instability indirectly by increasing exposure to the risk of other events, with varying implications for marital instability. For example, women who marry late are more likely to enter marriage with a child from a previous informal union and having cohabited with other partners - potentially destabilizing influences (Lehrer \& Chiswick, 1993; Liu, 2002; Waite \& Lillard, 1991); they are also more likely to have had the opportunity to complete a college education, a stabilizing influence (Lyngstad \& Jalovaara 2010; McLanahan, 2004). We use the 
term "total effect" to refer to the sum of the direct and indirect effects. Beyond these influences, part of the observed association between the wife's age at marriage and marital instability is spurious, reflecting the impact on each of these variables of the wife's personal and family background characteristics.

Using data from the 1960s, Becker et al. (1977) found evidence of a U-shaped relationship between age at first marriage and the probability of divorce, and interpreted the positive relationship emerging after age 30 as evidence of a dominant poor match effect at these later ages. Numerous subsequent studies found a strong negative relationship - often based on models with a linear age variable (e.g., Boheim \& Ermisch, 2001; Heaton, 2002). Analyses of cycles 5 (1995) and 6 (2002-2003) of the National Survey of Family Growth (NSFG), using a specification of the age variable that allows for non-linearities, revisited the possibility of a poor match effect (Lehrer, 2008). Women who delay marriage beyond the late twenties were found to disproportionately make unconventional matches, with characteristics that are typically associated with high marital instability (e.g., heterogamy in age, religion and education). Although this result suggests that Becker et al.'s (1977) poor match effect is indeed present, the findings also showed that the association between age at first marriage and marital instability (without controlling for the characteristics of the spouses at marriage) is strongly negative until the late twenties, with the curve leveling off thereafter, i.e., there is no U-shape.

In the present study, we show that both of the findings described above for the NSFG cycles 5 and 6 are replicated in the most recent NSFG cycle (2006 - 2010), and we go on from there to fill a gap in this literature: How can these patterns be explained? We develop and test competing hypotheses. In addition, noting that the trend towards delayed entry into marriage has been accompanied by higher proportions of women entering marriage with 16 years of schooling 
or more, we examine important changes across the NSFG cycles in the female education marital instability association.

\section{METHOD}

Conducted by the National Center for Health Statistics, the most recent NSFG questionnaires were addressed to nationally representative samples of men and women ages 1544 of all marital statuses living in the United States. The data were collected over an extended period: 2006-2010 (henceforth referred to as cycle 7, for brevity). The present study uses the female sample $(\mathrm{N}=12,279)$. As in the earlier study based on cycles 5 and 6 , only non-Hispanic white women were considered due to sample size limitations. This restriction led to a sample of $\mathrm{N}=6,301$ cases. Elimination of respondents who had never been married brought the sample to $\mathrm{N}=3$,209. After excluding observations with invalid data for the key variables, the final sample size was $\mathrm{N}=3,184$.

The associations of the wife's age at first marriage and other variables with marital instability were assessed using Cox proportional hazards models. Survival time was defined as the interval between the respondent's first marriage and the date of marriage dissolution, measured at the time of separation (or divorce, for cases with missing data on date of separation). First marriages that had not been dissolved were treated as censored as of the interview date; cases of widowhood were treated as censored at date of husband's death. In addition to the coefficients, standard errors and hazard ratios, we report estimated fifth-year dissolution probabilities - the complement of the survival function evaluated at 5 years and at selected values of the explanatory variables. 
Table 1 provides descriptive statistics for the variables used in the statistical analyses. The main explanatory variable - the wife's age at first marriage - was specified as a series of dummy variables. Consistent with the pattern of rising age at first marriage in recent decades, $26 \%$ of the marriages took place at age 27 or later - compared with $15 \%$ in cycle 5 and $23 \%$ in cycle 6.

We also included other variables that have been found to be risk factors for divorce in previous studies (see literature reviews by Lehrer, 2003; Lyngstad \& Jalovaara, 2010; Weiss, 1997). Among these are two characteristics of the wife's background - whether she lived in a non-intact family at age 14 and whether she was raised with no religious affiliation. Other variables indicate wife's characteristics at the time of first marriage: her education, whether she had had a child in a previous union, and a set of dummy variables indicating whether prior to the marriage she had cohabited with her spouse and/ or other partners. Finally, the analysis also includes characteristics of the husband and couple at the time of marriage: whether he had been married before, and dummy variables for race/ethnicity and age heterogamy. A limitation of the cycle 7 NSFG is that it did not collect information on two other important characteristics of the first husband: education and religion.

\section{RESULTS}

Table 2 reports the Cox proportional hazard regressions. Panel I, which controls only for the wife's background characteristics, provides an estimate of the influence of central interest: the total effect associated with the wife's age at first marriage. Panel II adds all the other explanatory factors. In the sections that follow, comparisons to results for the NSFG cycles 5 and 6 are based on findings reported in Lehrer (2008). 
Wife's Age at First Marriage

The estimates in Panel I show that the fifth-year dissolution probability is 0.32 for women who entered first marriage before age 20, and declines steadily to 0.09 for those who did so at age 30-32. The coefficient on the 30-32 age dummy is significantly different from that for the 27-29 age dummy ( $p=.06$ ). The probability rises slightly to 0.11 for ages 33 and older, but the coefficient on the dummy variable for the 33 and older category is not significantly different from that for the 30-32 category. The findings for cycles 5 and 6 of the NSFG showed that the curve indicating the total effect of age at marriage on marital instability is steeply downward sloping up to the late twenties, leveling off thereafter. The present results mirror those findings with one exception: the downward slope now extends farther, to the early thirties.

\section{Wife's Background Variables, Characteristics of Spouses at Marriage}

The estimated associations between the other variables and the odds of marital dissolution are generally in accordance with earlier findings in the literature and are described briefly. Panel I shows that marital instability is higher among respondents with a broken family background, lending support to numerous studies that show an intergenerational transmission of divorce (Amato, 1996). The point estimate of the effect associated with being raised with no religious affiliation is positive, consistent with results for cycles 5 and 6 of the NSFG, but the influence is no longer statistically significant. The proportion of women raised with no religion rose steadily across the three cycles, from 0.06 to 0.08 and 0.10 , consistent with other evidence of a growing representation of the unaffiliated in the population (Kosmin \& Keysar 2006). At the same time, the "no religion" category increasingly includes people for whom religion is part of 
their lives in the form of individualized belief systems (Ekelund, Hébert, \& Tollison, 2006). The lack of significance of the religion variable may reflect these forces.

In accordance with previous findings, the likelihood of experiencing marital instability is markedly lower for women who enter first marriage with 16 years of schooling or more (McLanahan, 2004), and substantially higher for those who do so having already had a child (Waite \& Lillard,1991). Unions involving a husband who had been previously married are more unstable, also consistent with results reported in previous studies (Castro-Martin \& Bumpass, 1989; Lyngstad \& Jalovaara, 2010).

Sharing living arrangements without the legal document of marriage may lead to behavioral changes conducive to higher marital instability (Thornton, Axinn, \& Hill, 1992); other research has emphasized the importance of selectivity factors (e.g., the lower commitment to marriage among those who cohabit) in explaining the generally positive association between premarital cohabitation and likelihood of divorce found in the literature (Lillard, Brien, \& White, 1995; Svarer, 2004). Approximately 36\% of respondents in cycle 5 had shared living arrangements with their spouse prior to marriage, and by cycle 6 the figure had risen to $50 \%$; the cycle 7 estimate presented in this paper is $58 \%$, consistent with the notion that premarital cohabitation is now the normative path towards formal marriage (Wilcox \& Marquardt, 2010). Although selectivity into cohabitation has diminished considerably, Table 2 shows a significant and sizeable destabilizing effect associated with cohabitation with the spouse only. A similar finding of lack of convergence was reported in comparisons covering marriages contracted over the period 1950 - 1984 (Teachman, 2002). Approximately 13\% of the cycle 7 sample reported having cohabited with the husband and also others, and another 3\% with others only; no significant effects can be discerned in connection with these variables. 
Earlier research has found that race/ ethnicity heterogamy has increased in recent decades, reflecting in part a more tolerant social environment (Amato, Johnson, \& Rogers, 2003). Consistent with these findings, $7 \%$ of marriages were heterogamous in race/ ethnicity in cycle 5, with an increase to $8 \%$ and $9 \%$ in cycles 6 and 7, respectively. At the same time, Table 2 shows evidence of a continued large destabilizing effect associated with race/ ethnicity heterogamy.

With regard to age differences between the spouses, there was an increase over the cycles in the proportion of couples with the husband older than the wife by 6 years or more, from $14 \%$ in cycle 5 to $16 \%$ in cycle 6 and $19 \%$ in cycle 7 . Theory predicts a positive sign for the effect of age heterogamy on marital instability (Becker, 1990). However, the sign for this form of age heterogamy actually ranges in earlier studies from significantly negative to significantly positive (Heaton, 2002; Lehrer, 1996; Teachman, 2002), possibly reflecting differences across studies in model specifications and related omitted variables biases (Lehrer, 2008). The cycle 6 estimates suggest that marital instability for these couples was lower than for their age-homogamous counterparts; no significant effects could be discerned in the cycle 5 data or the cycle 7 data analyzed here.

There was also an increase in the percentage of couples in which the wife was older than the husband by 3 years or more, from $2 \%$ in cycle 5 to $4 \%$ in cycles 6 and 7 , lending support to other research showing an increased prevalence of this particular form of age heterogamy as women have come to enjoy more equal opportunities in the labor market (Coles \& Francesconi, 2011). But as Table 2 shows, this form of age heterogamy continues to be associated with a sizeable increase in the probability of marital dissolution. 
Age at Marriage and Characteristics of the Match

Table 3 displays selected characteristics of the respondents and their partners by the wife's age at first marriage. Women who enter marriage in their late twenties or after are more likely than their counterparts who do so earlier to have completed 16 years of schooling or more, by a wide margin. Although cycle 7 of the NSFG does not contain information on the husband's education, patterns of assortative mating by education suggest that their husbands likely had high levels of schooling also (Fernandez \& Rogerson 2001; Kalmijn, 1991). In other observed dimensions of the match, however, women who married in their late twenties or later tended to form unions with characteristics found in earlier research to be asssociated with higher marital instability: they were more likely to wed men who had been previously married and who were younger than them by three years or more. These patterns closely mirror those uncovered earlier, for cycles 5 and 6, and are suggestive of a "poor-match effect" emerging as the biological clock begins to tick. Cycle 5, which contained richer data on husbands' characteristics, showed that women who postpone marriage are also more likely to enter unions that are heterogamous in two other important dimensions: education and religion. In addition, in all cycles, women who delay marriage themselves have characteristics associated with marital instability: they are more likely to have a child from a previous union and to have previously cohabited. Overall, these patterns suggest that women who marry in their late twenties or after disproportionately enter unconventional matches. At the same time, the absence of a U-shape in all cycles indicates that the unions they form tend to be solid.

Two different explanations may explain this puzzle. (a) One hypothesis is that whatever challenges these unconventional matches may pose, they can be addressed with the greater resources and higher maturity that come with more education and older ages, respectively. That 
is, the destabilizing effects typically associated with such factors as cohabitation before marriage, having a child from a previous union, a husband who was previously married, and age heterogamy, may simply not be present in couples that have delayed entry into marriage. (b) An alternative hypothesis is that these indicators of unconventional matches are always associated with higher marital instability - even in couples that have delayed entry to marriage - but the stabilizing effects associated with older ages and higher levels of educational attainment are larger and dominate.

\section{Subsample of Women who Delayed First Marriage}

To test these hypotheses, Panel III in Table 2 presents results for regressions estimated with the subsample of respondents who entered first marriage at age 27 or later. The sample size is $n=799$ and the coefficients are estimated with less precision. The direction of the effects, however, is clear. Although the coefficient on race/ ethnicity heterogamy is smaller and loses significance in the subsample, for all other traits, the magnitudes of the coefficients associated with characteristics that are generally destabilizing are at least as large in the subsample. This is true of a previous marriage of the husband, the wife being older than the husband by three years or more, and cohabitation prior to the marriage with the spouse only. Moreover, the dummy variable indicating cohabitation with others only is now significantly positive at the 0.10 level and large in magnitude. Overall, the results are strongly supportive of hypothesis (b) above.

Examination of the predicted probabilities is instructive. The reference woman for the regression in Table 2, Panel II (full sample) entered first marriage at age 20-26 with 12-15 years of schooling. Her counterpart in Panel III (subsample) entered first marriage at age 27-29 having completed 16 years of schooling or more, the modal education for this group. As an illustration, 
Panel III shows that in the subsample, the fifth-year dissolution probability for a couple in which the husband had been married before is 0.09 , compared to 0.06 if he had not. By comparison, Panel II, for the full sample, shows that the corresponding probabilities are 0.23 and 0.19 . These results illustrate the relative stability of unions that begin later in life with high educational levels, even in the case of unconventional matches.

Wife's Education at Marriage - Comparisons Across Cycles 5, 6 and 7

The simple statistics on median age at first marriage with which we opened this paper mask considerable variation by education. The cross-tabulations in Table 3 indicate that it is the most highly educated women who are delaying entry to first marriage, and the hazards models in Table 2 show that it is these women who are going on to solid unions - both their high education and their older age at marriage contribute to marital stability. These patterns mirror previous findings for cycles 5 and 6.

The proportion of women who entered first marriage with 16 years of schooling or more rose from 0.16 in cycle 5 to 0.28 in cycle 6 and to 0.31 in cycle 7 . In addition, Table 4 shows that two notable changes took place across the cycles in the education-marital instability association. First, in cycle 5, the marriages of women who had completed 12-15 years of schooling were more stable than those of their high-school dropout counterparts by a modest margin: a fifth-year dissolution probability of 0.13 as compared to 0.16 . In contrast, the cycle 6 estimates showed no significant difference between these two groups, and that pattern also prevails in the cycle 7 estimates presented here. These findings are consistent with recent research showing that the “moderately educated middle” (i.e., those who do not have a four-year college degree but have completed high school) increasingly resemble high school dropouts in their patterns of divorce, 
and also of marriage, non-marital fertility, and other demographic and economic behaviors (Wilcox \&Marquardt, 2010). Further studies on the seeming disappearance of "middle America" - assessing the robustness of these findings with other data sets and methodologies - will undoubtedly be a high priority in the research agenda in years to come.

Second, the gap in the fifth-year dissolution probability between women with 16 years of schooling or more and their counterparts with 12-15 years grew from 3 percentage points in cycle 5, to 8 percentage points in cycles 6 and 7. Related research has noted that more and less advantaged SES groups in the U.S. have been following divergent trajectories, not only in the patterns of age at marriage and divorce discussed here, but also in trends of female employment, out-of-wedlock childbearing, and fathers’ involvement with children. The result has been a widening gap in resources available to children from these groups as the second demographic transition has unfolded (McLanahan, 2004). The divergence has been caused partly by rising income inequality spurred by technological change and globalization, and partly by major socioeconomic and cultural transformations including changes in women's bargaining power brought about by the contraceptive revolution (Akerlof, Yellen, \& Katz, 1996; Lemieux, 2008;

McLanahan, 2004).

\section{DISCUSSION}

Analyses of data from the 2006-2010 NSFG cycle show that women who delay first marriage disproportionately enter unions having completed 16 years of schooling or more (and their husbands likely have similarly high levels of education); in other respects, however, their marriages tend to have characteristics that traditionally have been associated with high marital instability, including age heterogamy and a previous marriage of the husband. At the same time, the unions they form tend to be solid. Both of these results are consistent with earlier findings 
based on cycles 5 and 6 of the NSFG. The analyses in this paper shed light on these patterns and provide an interpretation. Re-estimation of the model with the subsample of respondents who delayed entry to first marriage found that those traits that are associated with unconventional matches are generally destabilizing for these women also. But the stabilizing effects associated with the greater maturity that comes with older ages and the higher level of economic resources that come with more schooling are far larger in magnitude.

Having emphasized the flattening out of the curve at late ages at marriage - the U-shape postulated by Becker et al. (1977) is not there - the most salient aspect of the age at marriagemarital instability relationship is the steep downward sloping curve from the teens to the late twenties in cycles 5 and 6 , and to the early thirties in cycle 7. It is important to note that while marriages that take place before age 20 are by far the most unstable, the difference in the estimated fifth-year dissolution probabilities for marriages contracted at ages 20-26 versus 30-32 is also sizeable - 11 percentage points. That is, the pronounced negative relationship between age at first marriage and marital instability is not driven just by unstable marriages contracted at very young ages, as suggested in earlier scholarly research (Glenn, Uecker, \& Love, 2010; Heaton, 2002) and the popular press (Regnerus, 2009).

The divorce rate has been declining in the U.S. since the early 1980s (Cherlin, 2010; Isen \& Stevenson, 2012; Stevenson \& Wolfers, 2007). The present findings suggest that an important item in the agenda for future research is quantifying the extent to which this decline over time can be accounted for by the three major trends emphasized in this paper: (a) the tendency to enter marriage at later ages, (b) the increased levels of men's and women's education at marriage, and (c) the widening gap in marital instability between women with a college education and their less educated counterparts. Research that focused on the first of these factors found that it could 
explain at least $60 \%$ of the decline in divorce for cohorts entering marriage in the period 19802004 (Rotz, 2012).

A recent study cautions that although marriages contracted at late ages may be stable, such marriages disproportionately include marital unions of low quality, as measured by responses to questions about happiness and satisfaction with the marriage (Glenn et al., 2010). In another study, however, an older age at marriage was associated with a lower proneness to divorce, and the associations between age at marriage and two other subjective measures of marital quality were insignificant (Amato et al., 2003). More recent research has found that marriages contracted later in life tend to display objective characteristics associated with better marriages, such as fewer arguments, healthier ways of dealing with disagreements, a lower likelihood of physical injury during an argument, and a more egalitarian intra-household division of labor (Rotz, 2012). Further research along these lines would be desirable. In the meantime, the real concern is with the non-college educated who tend to marry at young ages, and for whom the divorce rate has stayed the same (high school degree or some college) or even increased (high-school dropouts); this is also a group with a high rate of childbearing within the context of fragile cohabiting unions (Cherlin, 2009, 2010; Martin, 2006).

The proportional hazards models in Table 2 control for factors found in earlier studies to be predictive of divorce - wife’s family background variables (Panel I), and characteristics of the spouses at marriage (Panel II). But of course there is a host of unobserved relevant factors in each of these categories. In particular, our estimate of the "total effect" in Panel I must be qualified as subject to omitted variables biases. A recent study focusing on the adverse effect of marriage at very young ages on subsequent economic status was able to obtain a consistent estimate by using variations across states in minimum-age-at-marriage laws as an instrument 
(Dahl, 2005). A similar approach could be used to obtain a consistent estimate of the adverse effect on marital stability, using data sets that include information on state of residence at the time of marriage; however, the pronounced non-linearities uncovered in the present study indicate that simple extrapolation to the older ages - the late twenties and beyond - would be inappropriate.

The findings of this study raise two important questions for future research on marriage and the family. The first pertains to changes over time in the extent of positive assortative mating in the marriage market. Recent research has developed the idea that the U.S. has witnessed a shift in gains from marriage from production efficiencies (based on intra-household division of labor and specialization) to consumption complementarities, likely contributing to a decrease in heterogamy over time (Isen \& Stevenson, 2012). As the authors note (p. 4), "in a consumptionbased model of marriage people will be more likely to marry someone with similar preferences, which will likely manifest itself as an increase in positive assortative mating along dimensions such as age, educational background, occupation, as well as consumption, and leisure preferences.” The “poor match” effect, first suggested by Becker et al. (1977), revisited here, suggests that the pattern of delayed entry into first marriage has exerted an influence in the opposite direction, leading to an increase over time in heterogamy. Further analyses of these countervailing forces may shed light on the complex patterns that have emerged in studies to date, which show that heterogamy has increased in some dimensions and decreased in others (Amato et al., 2003; Cherlin, 2010, Kalmijn, 1991; Schwartz \& Mare, 2005; Qian, 1998). In particular, our findings suggest the desirability of taking into account age at marriage in future analyses of trends in assortative mating. 
The second question pertains to the extensive literature showing that differences between the partners in religious affiliation are associated with a higher probability of marriage dissolution (Kalmijn, Graaf \& Janssen, 2005; Lehrer, 2009; Lehrer \& Chiswick 1993; Vaaler, Ellison \& Powers, 2009). The present results suggest that although inter-faith marriages contracted at a late age may be significantly less solid than intra-faith marriages also contracted at a late age, overall they are likely to be very stable. The same remarks apply to the destabilizing effects typically associated with education heterogamy. A fruitful avenue for further research is to formally test these hypotheses with richer data sets containing information on husband's religion and education. 


\section{REFERENCES}

Akerlof, G. A., Yellen, J. L., \& Katz, M. I. (1996). An analysis of out-of-wedlock childbearing in the United States. Quarterly Journal of Economics, 111, 277 317.

Amato, P. R. (1996). Explaining the intergenerational transmission of divorce. Journal of Marriage and the Family, 58, 628 -640.

Amato, P. R., Johnson, D. R., Booth, A., \& Rogers, S. J. (2003). Continuity and change in marital quality between 1980 and 2000. Journal of Marriage and the Family, 65, 1 - 22.

Becker, G. S. (1973). A theory of marriage. In T. W. Schultz (Ed.) Economics of the Family: Marriage, Children, and Human Capital (pp. 299-344). Chicago: The University of Chicago Press.

Becker, G. S. (1990). A Treatise on the Family. Cambridge: Harvard University Press.

Becker, G., Landes, E. M., \& Michael, R. T (1977). An economic analysis of marital instability. Journal of Political Economy, 85(6), 1141 - 1187.

Boheim, R., \& Ermisch, J. (2001). Partnership dissolution in the UK: The role of economic circumstances. Oxford Bulletin of Economics and Statistics, 63(2), 197 - 208.

Castro-Martin B., \& Bumpass, L. L. (1989). Recent trends in marital disruption. Demography, 26(1), 37-52.

Cherlin, A. J. (2004). The deinstitutionalization of American marriage. Journal of Marriage and the Family, 66, 848 - 861.

Cherlin, A. J. (2009). Rebuttal: Real wedding bell woes. The Washington Post, April 27. 
Cherlin, A. J. (2010). Demographic trends in the United States: A review of research in the 2000s. Journal of Marriage and the Family, 72: 403 - 419.

Coles, M. G., \& Francesconi, M. (2011). On the emergence of toyboys: The timing of marriage with aging and uncertain careers. International Economic Review, 52(3), $825-853$.

Dahl, G. B. (2005). Early teen marriage and future poverty. National Bureau of Economic Research, Working Paper \#11328.

Ekelund, R. B., Hébert, R. F., \& Tollison, R. D (2006). The Marketplace of Christianity. Cambridge: The MIT Press.

Fernandez, R., \& Rogerson R (2001). Sorting and long-run inequality. Quarterly Journal of Economics, 116, 1305 - 1341.

Glenn, N. D., Uecker, J. E., \& Love, R. W. B (2010). Later first marriage and marital success. Social Science Research, 39, 787 - 800.

Goldin, C., \& Katz, L. (2002). The power of the pill: Oral contraceptives and women's career and marriage decisions. Journal of Political Economy, 110(4), 730 - 770.

Greenwood, J., \& Guner, N. (2008). Marriage and divorce since World War II: Analyzing the role of technological progress on the formation of households. National Bureau of Economic Research Macro Annual. Cambridge: NBER.

Heaton, T. B. (2002). Factors contributing to increasing marital instability in the United States. Journal of Family Issues, 23, 392 - 409.

Isen, A., \& Stevenson, B. (2012). Women's education and family behavior: Trends in marriage, divorce and fertility. Forthcoming in Demography.

Kalmijn, M. (1991). Shifting boundaries: Trends in religious and educational homogamy. American Sociological Review, 56, 768 - 780. 
Kalmijn, M., de Graaf, P. M., \& Janssen, J. P. G. (2005). Intermarriage and the risk of divorce in the Netherlands: The effects of differences in religion and nationality. Population Studies, 59(1), 71 - 85.

Kosmin, B. A. \& Keysar, A. (2006). Religion in a Free Market. Ithaca, New York: Paramount Market Publishing, Inc.

Lehrer, E. L. (1996). The determinants of marital stability: A comparative analysis of first and higher-order marriages. Research in Population Economics, 8, 91-121.

Lehrer, E. L. (2003). The economics of divorce. In S. Grossbard-Shechtman (Ed.) Marriage and the Economy: Theory and Evidence from Industrialized Societies (pp. 55 - 74). Cambridge: Cambridge University Press.

Lehrer, E. L. (2008). Age at marriage and marital instability: Revisiting the BeckerLandes-Michael hypothesis. Journal of Population Economics, 21(2), 463 - 484.

Lehrer, E. L. (2009). Religion, Economics, and Demography: The Effects of Religion on Education, Work, and the Family. London: Routledge Press.

Lehrer, E. L., \& Chiswick, C. U. (1993). Religion as a determinant of marital instability. Demography, 30(3), 385 - 404.

Lemieux, T. (2008). The changing nature of wage inequality. Journal of Population Economics, 21, 21 - 48.

Lillard, L., Brien, M. J., \& Waite, L. J. (1995). Pre-marital cohabitation and subsequent marital dissolution: Is it self-selection? Demography, 32(3), 437 -458.

Liu, G. (2002). How premarital children and childbearing in current marriage influence divorce of Swedish women in their first marriages. Demographic Research, 7, article 10: 389 - 406.

Lyngstad, T. H. \& Jalovaara, M. (2010). A review of the antecedents of union dissolution. Demographic Research 23, article 10:257-292. 
Martin, S. P. (2006). Trends in marital dissolution by women's education in the United States. Demographic Research, 15(20), 537 - 560.

McLanahan, S. (2004). Diverging destinies: How children fare under the second demographic transition. Demography, 41(4), 607 - 628.

Oppenheimer, V. K. (1988). A theory of marriage timing. American Journal of Sociology, 94(3), 563 - 591.

Qian, Z. (1998). Changes in assortative mating: The impact of age and education, 19701990. Demography, 35(3), 279 - 292.

Regnerus, M. (2009). Say yes: What are you waiting for? The Washington Post, April 26.

Rotz, D. (2012). Why have divorce rates fallen? The role of women's age at marriage. Unpublished manuscript, Harvard University.

Schwartz, C. R., \& Mare, R.D. (2005). Trends in educational assortative marriage from 1940 to 2003. Demography, 42, 621 - 646.

Stevenson, B. \& Wolfers, J. (2007). Marriage and divorce: Changes and their driving forces. Journal of Economic Perspectives, 21(2), 27 - 52.

Svarer, M. (2004). Is your love in vain? Another look at premarital cohabitation and divorce. Journal of Human Resources, 39(2), 523 - 535.

Teachman, J. D. (2002). Stability across cohorts in divorce risk factors. Demography, 39(2), 331-351.

Thornton, A., Axinn, W. G., \& Hill, D. H. (1992) Reciprocal effects of religiosity, cohabitation, and marriage. American Journal of Sociology, 98(3), 628 - 651.

U.S. Census Bureau (2010). www.census.gov/population/socdemo/hh-fam/ms2.xls Last accessed: May 17, 2012.

Vaaler, M. L., Ellison, C. G., \& Powers, D. A. (2009). Religious influences on the risk of marital dissolution. Journal of Marriage and the Family, 71(4), 917 - 934. 
Waite, L., \& Lillard, L. (1991). Children and marital disruption. American Journal of Sociology, 96(4), 930 - 953.

Weiss, Y. (1997). The formation and dissolution of families: Why marry? Who marries whom? And what happens upon divorce? In M. R. Rosenzweig \& O. Stark (Eds.) Handbook of Population and Family Economics, V 1A (pp. 81 - 123). Amsterdam: Elsevier.

Weiss, Y., \& Willis, R. J. (1997). Match quality, new information, and marital dissolution. Journal of Labor Economics, 15(1), S293 - S329.

Wilcox, W. B., \& Marquardt, E. (Eds.) (2010). The State of our Unions, 2010. Charlottesville, Virginia: The National Marriage Project and the Institute for American Values. 
Table 1. Descriptive Statistics

\begin{tabular}{|c|c|c|}
\hline Variable & Definition & Mean \\
\hline Wife's Age at Marriage & $\begin{array}{l}=1 \text { if respondent's }(\mathrm{R}) \text { age at marriage was in category } \\
\text { indicated }\end{array}$ & \\
\hline Less than 20 & & 0.16 \\
\hline$(20-26)$ & & $(0.59)$ \\
\hline $27-29$ & & 0.14 \\
\hline $\begin{array}{l}30-32 \\
33 \text { or older }\end{array}$ & & $\begin{array}{l}0.07 \\
0.05\end{array}$ \\
\hline \multicolumn{3}{|l|}{$\begin{array}{l}\text { Wife's Background } \\
\text { Characteristics }\end{array}$} \\
\hline Family of origin not intact & $=1$ if R's family of origin was not intact & 0.33 \\
\hline Unaffiliated & $=1$ if $\mathrm{R}$ was raised with no religious affiliation & 0.10 \\
\hline \multicolumn{3}{|l|}{$\begin{array}{l}\text { Wife's Characteristics at } \\
\text { Marriage }\end{array}$} \\
\hline Education & $\begin{array}{l}=1 \text { if at date of first marriage, R's education was in } \\
\text { category indicated }\end{array}$ & \\
\hline $\begin{array}{l}\text { Less than } 12 \text { years } \\
\text { (12 - } 15 \text { years) } \\
16 \text { years or more }\end{array}$ & & $\begin{array}{c}0.15 \\
(0.54) \\
0.31\end{array}$ \\
\hline Child from previous union & $\begin{array}{l}=1 \text { if } \mathrm{R} \text { had had a live birth prior to the date of first } \\
\text { marriage }\end{array}$ & 0.19 \\
\hline
\end{tabular}


Table 1 (continued)

\begin{tabular}{|c|c|c|}
\hline Variable & Definition & Mean \\
\hline \multicolumn{3}{|l|}{ Cohabitation before marriage } \\
\hline With spouse only & $\begin{array}{l}=1 \text { if } \mathrm{R} \text { only cohabited with husband prior to } \\
\text { marriage }\end{array}$ & 0.45 \\
\hline With spouse and others & $\begin{array}{l}=1 \text { if } \mathrm{R} \text { cohabited with husband and others } \\
\text { prior to marriage }\end{array}$ & 0.13 \\
\hline With others only & $\begin{array}{l}=1 \text { if } \mathrm{R} \text { only cohabited with others prior to } \\
\text { marriage }\end{array}$ & 0.03 \\
\hline \multicolumn{3}{|c|}{$\begin{array}{l}\text { Characteristics of husband and } \\
\text { couple at marriage }\end{array}$} \\
\hline Husband married before & $=1$ if R's husband had been married before & 0.15 \\
\hline Different race/ ethnicity & $=1$ if husband is non-white and/or Hispanic & 0.09 \\
\hline Age composition & $\begin{array}{l}=1 \text { if difference between husband's and wife's } \\
\text { age is as indicated }\end{array}$ & \\
\hline 6 years or more & & 0.19 \\
\hline-3 years or less & & 0.04 \\
\hline (more than -3 ; less than 6 ) & & $(0.77)$ \\
\hline $\mathrm{N}$ & & 3,184 \\
\hline
\end{tabular}


Table 2. Cox Proportional Hazards Models of Marital Dissolution (standard errors in parentheses)

\begin{tabular}{|c|c|c|c|c|c|c|c|c|c|}
\hline & \multicolumn{3}{|c|}{$\begin{array}{l}\text { Panel I: Controlling only for wife's } \\
\text { background characteristics }\end{array}$} & \multicolumn{3}{|c|}{$\begin{array}{l}\text { Panel II: Adding characteristics of } \\
\text { spouses at marriage }\end{array}$} & \multicolumn{3}{|c|}{$\begin{array}{l}\text { Panel III: Subsample } \\
\text { Wife’s age at marriage } 27+\end{array}$} \\
\hline & Coefficient & $\begin{array}{l}\text { Hazard } \\
\text { Ratio }\end{array}$ & $\begin{array}{c}5^{\text {th }} \text { year } \\
\text { dissolution }^{\text {probability }}\end{array}$ & Coefficient & $\begin{array}{l}\text { Hazard } \\
\text { Ratio }\end{array}$ & $\begin{array}{c}5^{\text {th }} \text { year } \\
\text { dissolution } \\
\text { probability }\end{array}$ & Coefficient & $\begin{array}{l}\text { Hazard } \\
\text { Ratio }\end{array}$ & $\begin{array}{c}5^{\text {th }} \text { year } \\
\text { dissolution } \\
\text { probability }\end{array}$ \\
\hline $\begin{array}{l}\text { Wife's Age at } \\
\text { Marriage }\end{array}$ & & & & & & & & & \\
\hline $\begin{array}{l}\text { Less than } 20 \\
20-26\end{array}$ & $0.53(0.07)^{* *}$ & 1.69 & $\begin{array}{l}0.32 \\
0.20\end{array}$ & $0.44(0.08)^{* *}$ & 1.55 & $\begin{array}{l}0.28 \\
0.19\end{array}$ & & & \\
\hline $27-29$ & $-0.47(0.11)^{* *}$ & 0.63 & 0.13 & $-0.43(0.12)^{* *}$ & 0.65 & 0.13 & & & 0.06 \\
\hline $30-32$ & $-0.87(0.19)^{* *}$ & 0.42 & 0.09 & $-0.84(0.20)^{* *}$ & 0.43 & 0.09 & $-0.43(0.22)^{* *}$ & 0.65 & 0.04 \\
\hline 33 or older & $-0.62(0.23)^{* *}$ & 0.54 & 0.11 & $-0.49(0.24)^{* *}$ & 0.61 & 0.12 & $-0.09(0.26)$ & $(0.91)$ & $(0.05)$ \\
\hline $\begin{array}{l}\text { Wife's Background } \\
\text { Characteristics }\end{array}$ & & & & & & & & & \\
\hline $\begin{array}{l}\text { Family of origin } \\
\text { not intact }\end{array}$ & $0.45(0.06)^{* *}$ & 1.57 & 0.30 & $0.31(0.06)^{* *}$ & 1.36 & 0.25 & $0.12(0.19)$ & (1.13) & $(0.07)$ \\
\hline Unaffiliated & $0.13(0.09)$ & $(1.14)^{\mathrm{b}}$ & $(0.23)$ & $0.10(0.09)$ & $(1.11)$ & $(0.21)$ & $0.14(0.27)$ & $(1.14)$ & $(0.07)$ \\
\hline $\begin{array}{l}\text { Wife's } \\
\text { Characteristics at } \\
\text { Marriage } \\
\text { Education }\end{array}$ & & & & & & & & & \\
\hline $\begin{array}{l}\text { Less than } 12 \text { years } \\
12-15 \text { years }\end{array}$ & & & & $-0.02(0.08)$ & $(0.98)$ & $(0.19)$ & $-0.33(0.28)$ & $(0.72)$ & $\begin{array}{c}(0.08) \\
0.10\end{array}$ \\
\hline 16 years or more & & & & $-0.66(0.09)^{* *}$ & 0.52 & 0.11 & $-0.59(0.21)^{* *}$ & 0.56 & \\
\hline $\begin{array}{l}\text { Child from } \\
\text { previous union }\end{array}$ & & & & $0.27(0.08)^{* *}$ & 1.31 & 0.24 & $0.75(0.21)^{* *}$ & 2.11 & 0.12 \\
\hline
\end{tabular}


Table 2 (continued)

\begin{tabular}{|c|c|c|c|c|c|c|c|c|c|}
\hline & \multicolumn{3}{|c|}{ Panel I } & \multicolumn{3}{|c|}{ Panel II } & \multicolumn{3}{|c|}{ Panel III: subsample } \\
\hline & Coefficient & $\begin{array}{l}\text { Hazard } \\
\text { Ratio }\end{array}$ & $\begin{array}{c}5^{\text {th }} \text { year } \\
\text { dissolution } \\
\text { probability }\end{array}$ & Coefficient & $\begin{array}{l}\text { Hazard } \\
\text { Ratio }\end{array}$ & $\begin{array}{c}5^{\text {th }} \text { year } \\
\text { dissolution } \\
\text { probability }\end{array}$ & Coefficient & $\begin{array}{l}\text { Hazard } \\
\text { Ratio }\end{array}$ & $\begin{array}{c}5^{\text {th }} \text { year } \\
\text { dissolution } \\
\text { probability }\end{array}$ \\
\hline \multicolumn{10}{|c|}{ Cohabitation before marriage } \\
\hline With spouse only & & & & $0.25(0.07)^{* *}$ & 1.28 & 0.24 & $0.41(0.25)^{*}$ & 1.51 & 0.09 \\
\hline With spouse and others & & & & $-0.01(0.12)$ & $(0.99)$ & $(0.19)$ & $-0.10(0.31)$ & $(0.90)$ & $(0.05)$ \\
\hline With others only & & & & $0.29(0.20)$ & $(1.34)$ & $(0.25)$ & $0.79(0.45)^{*}$ & 2.21 & 0.12 \\
\hline \multicolumn{10}{|c|}{$\begin{array}{l}\text { Characteristics of Husband } \\
\text { and Couple at Marriage }\end{array}$} \\
\hline Husband married before & & & & $0.18(0.09)^{* *}$ & 1.20 & 0.23 & $0.45(0.21)^{* *}$ & 1.57 & 0.09 \\
\hline Different race/ethnicity & & & & $0.42(0.09)^{* *}$ & 1.52 & 0.28 & $0.31(0.28)$ & $(1.36)$ & $(0.08)$ \\
\hline \multicolumn{10}{|l|}{ Age difference } \\
\hline 6 years or more & & & & $-0.01(0.08)$ & $(0.99)$ & $(0.19)$ & $-0.08(0.23)$ & $(0.92)$ & $(0.05)$ \\
\hline-3 years or less & & & & $0.33(0.19)^{*}$ & 1.39 & 0.26 & $0.49(0.25)^{* *}$ & 1.63 & 0.09 \\
\hline
\end{tabular}

$\mathrm{N}=3,184$ for Panels I and II; $\mathrm{n}=799$ for Panel III.

a The reference person in Panel I is a respondent who entered first marriage at age 20-26 and whose family background characteristics are typical, i.e., they are set at the modal category. The other estimated fifth-year dissolution probabilities correspond to respondents who differ from the reference person in only one trait, as noted in the stub.

The reference person in Panel II entered marriage at age 20-26 with 12-15 years of schooling, and all others characteristics of the wife, husband and couple are also set at the mode.

The reference person in Panel III is defined in a similar way. Her age at first marriage and education are set at 27-29 and 16 years or more, respectively, the modal categories for this group.

b Hazard ratios and probabilities are shown in parentheses when the corresponding coefficient is not significant at the 0.10 level.

** $p<.05 ; * p<.10$ 
Table 3. Selected Characteristics by Respondent's Age at Marriage ${ }^{a}$

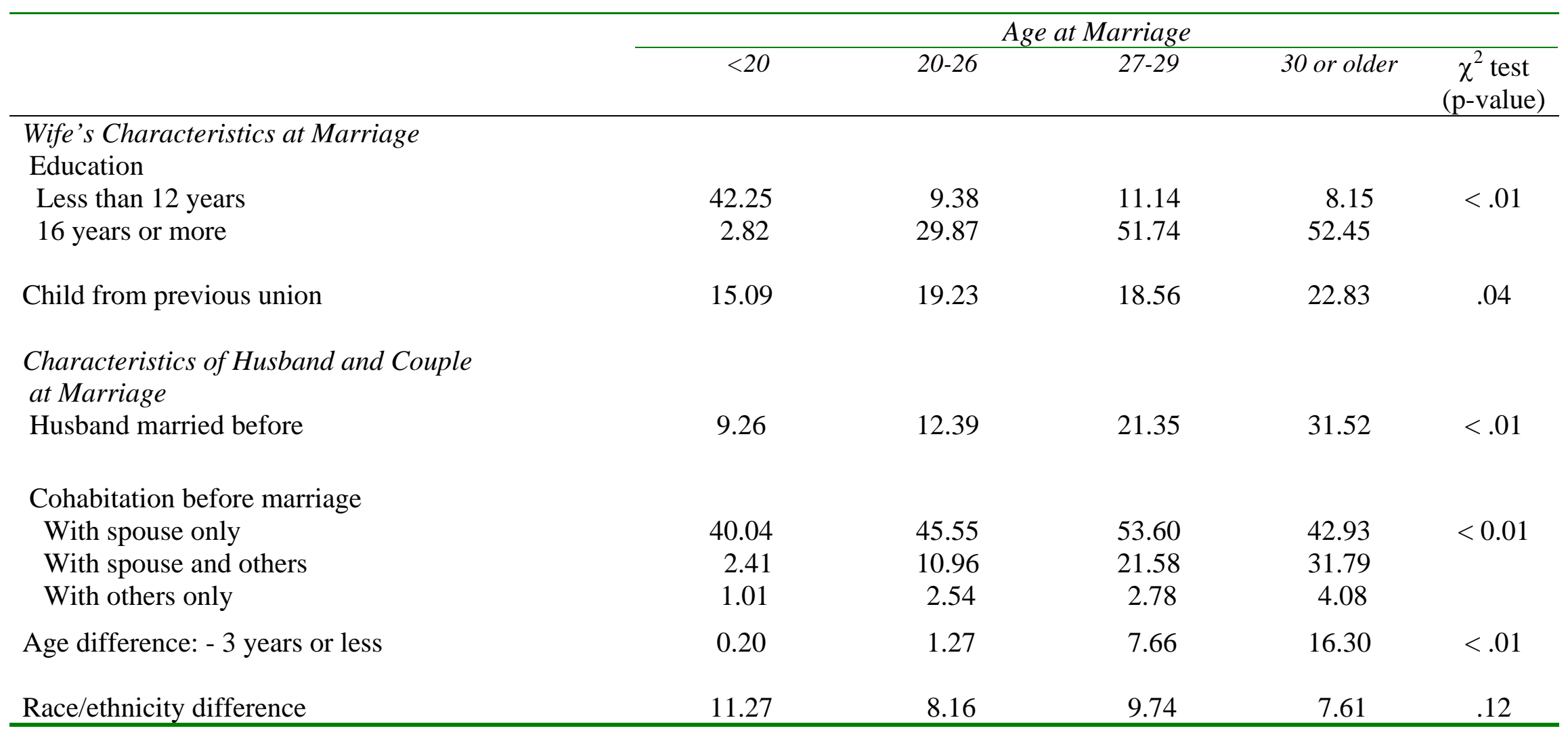

$\mathrm{N}=3,184$

${ }^{\text {a }}$ Figures reported are percentage of cases with dummy variable equal to 1. 
Table 4. Changes across Cycles in Association between Wife's Education and Marital Instability

Estimated Fifth-Year Dissolution Probabilities ${ }^{a}$

\begin{tabular}{llll}
\hline & Cycle 5 & Cycle 6 & Cycle 7 \\
\hline Wife’s education & & & \\
Less than 12 years & 0.16 & $(0.23)^{\mathrm{b}}$ & $(0.19)$ \\
12-15 years (reference) & 0.13 & 0.21 & 0.19 \\
16 years or more & 0.10 & 0.13 & 0.11 \\
$\mathrm{~N}$ & 4,413 & 2,437 & 3,184 \\
\hline
\end{tabular}

a These probabilities are based on the full models - the specifications that include all characteristics of spouses. The reference person entered marriage at age 20-26 and has other characteristics also set at the modal category.

b Probabilities shown in parentheses correspond to coefficients on dummy variables that were not significantly different from the reference category at the .10 level. 